\title{
Performance Outcome of Market Orientation Behaviours among Botswanas’ Small Service Firms
}

\author{
Olumide Olasimbo Jaiyeoba \\ Department of Marketing \\ University of Botswana, Gaborone, Botswana \\ E-mail: olujaiyeoba@yahoo.com
}

Received: Nov. 11, 2013

Accepted: December 6, 2013 Published: January 1, 2014

doi:10.5296/jmr.v6i1.4535

URL: http://dx.doi.org/10.5296/jmr.v6i1.4535

\begin{abstract}
A vast majority of the stream concerning Market Orientation (MO) consequences have concentrated on its relationship with business performance (Narver and Slater,1990;Jaworski and Kholi,1993;Kuada and Buatsi,2005;Pelham,2000 and Dwairi et al.,2007).Few works have however addressed other possible consequences, such as the effect of MO on the operational level of employees (Jaworski and Kholi,1993;Ruekert,1992;Zebal \& Goodwin.,2011),or the effect of MO at a customer level (Krekapa et al.,2003;Zebal \& Goodwin.,2011). This limited amount of research is somewhat surprising given that employees 'attitudes and behaviours, and customer satisfaction (non economic performance), as well as business performance (economic performance) are central pillars that have been widely recognized in the conceptualization of MO (Kholi and Jaworski,1990 and Narver and Slater,1990). The effects of MO on both job related attitudes have been studied by relevant literature. The studies conducted by Jaworski and Kholi (1993),Marandu \& Themba.,(2012) and Jones et al.,(2003) are some examples that underline the positive consequences of MO on these job related employee attitudes. The multivariate analysis techniques (MANOVA) was used in this study to explicate the nomological web between overall market orientation and economic and noneconomic performance of small service firms. This study contributes to that body of literature by investigating the consequences of market orientation in Botswana. The results successfully replicate the Jaworski and Kholi findings, within the Botswana's environment. The findings also provide evidence that performance outcomes can be enhanced by the adoption of market orientation in Botswana.
\end{abstract}

Keywords: Performance Outcomes, Market Orientation, Small Businesses, Botswana 


\section{Introduction}

Over the last decade, marketing literature has acknowledged the role of market orientation as a major source of achieving a sustainable competitive advantage. A vast majority of the stream concerning MO consequences have concentrated on its relationship with business performance (Narver and Slater,1990;Jaworski and Kholi,1993; Kuada and Buatsi,2005; Pelham,2000 and Dwairi et al.,2007). Few works have however addressed other possible consequences,such as the effect of MO on the operational level of employees (Jaworski and Kholi,1993;Ruekert,1992; Zebal \& Goodwin.,2011), or the effect of MO at a customer level (Krekapa et al.,2003; Zebal \& Goodwin.,2011). This limited amount of research is somewhat surprising given that employees 'attitudes and behaviours, and customer satisfaction (non economic performance), as well as business performance (economic performance) are central pillars that have been widely recognized in the conceptualization of MO (Kholi and Jaworski,1990 and Narver and Slater,1990).The effects of MO on both job related attitudes have been studied by relevant literature. The studies conducted by Jaworski and Kholi (1993),Marandu \&Themba.,(2012) and Jones et al.,(2003) are some examples that underline the positive consequences of MO on these job related employee attitudes. Kholi and Jaworski,(1990) concluded that the reasoning behind this link is that MO raises employee morale, job satisfaction, and commitment to the organization because all departments work toward the common goal of customer satisfaction. This research thus seeks to investigate the performance outcome of market orientation behaviour among Botswanas'small service firms.

Despite the fact that some scholars identified a strong positive correlation between market orientation and business performance (Greenley, 1995; Matsuno et al., 2002; and Kara, 2005; Vieira, 2010), others have reported mixed findings (Jaworski and Kohli, 1993; Han et al., 1998; and Pelham, 2005). Therefore, the anecdotal research conducted on market orientation and the mixed findings reported, complicate efforts amongst both academics and practitioners to conclude on the real effects of the construct upon business performance (Dauda, 2010). This is exacerbated by the absence of empirical research conducted on market orientation construct in Botswana.Accordingly,there are many calls for market orientation research in Low income Countries (e.g., Kuanda \& Buatsi,cited in Burgess et al.,2007). The acute paucity represent both an empirical and theoretical gap to which this study seek to fill, using MARKOR scale, with the service small and medium sized enterprises as a study context.Building on the initial research by Kholi and Jaworski \&Kumar,(1990); Narver \& Slater, (1990) and Deshpande et al., (1993), significant progress has been made in conceptualization and measurement of market orientation and its impact on business performance. In contrast, the issues relating to the determinants and development of market orientation are still relatively under researched, especially in developing countries. This research is consistent with Narver and Slater's suggestion that market orientation research must be replicated in diverse cultures to boost conviction in nature and power of market orientation and its antecedents. Hence, current study is an attempt to retest the market orientation model, proposed by Kholi \& Jaworski,(1990) to determine which organisational factors could contribute in making Botswana service small business firms, more market 
oriented. Based on research findings, the exploration of organisational factors will facilitate leadership of service small business firms in Botswana in designing and implementing business practices and processes, aimed at becoming more market oriented which would result in improved business effectiveness and sustained competitive advantage.

Research on market orientation in the service industry in Botswana is clearly justified. On one hand, researchers in the field of marketing have claimed the need to expand the construct to new areas; on the other hand, service firms are becoming market oriented, requiring theoretical frames and empirical analysis.Thus,the explanation of factors promoting a market orientation and its consequences may better explain the dynamics of the construct in the field under research.

\subsection{Background Information of the study}

The population of Botswana is estimated to be about 2 million, currently ranked as an upper middle-income country with per capita income in excess of US\$5,000 (Local Enterprise Authority, 2007). SMMEs play a crucial role towards achieving industrial and economic development objectives of the Botswana economy (Local Enterprise Authority, 2009). There is no standard definition of SMMEs, but rather definitions vary from country to country, depending largely on the size of a given economy and the levels of development. The most common parameters used to categorize SMMEs are the annual turnover and the number of workers. However, the policy report documented in the Government paper 1 (1999) notes that some countries tend to have a higher threshold figures for numbers of employees and turnover. Nevertheless, Botswana, Government paper No1 of (1999), provides a comprehensive categorization of SMMEs that will be adopted for this thesis.

SMMEs are faced with a multiplicity of constraints including but not limited to, lack of access to finance, lack of entrepreneurial skills, shortage of business premises, excessive government regulations, lack of marketing skills, inherent biases against SMMEs (Government paper, 1999). SMMEs low survival rates as a result of 'would be entrepreneurs' exploiting government schemes as a means of cheap funding and not necessarily interested in establishing a business is also a major concern (Hinton et al, 2006). This is consistent with the earlier report that noted that there seem to be a high failure rate of SMMEs in Botswana, with $80-85 \%$ of such enterprises disappearing within five years of startup (Government paper, 1998). The report adds that a substantial proportion of micro enterprises however, neither disappear nor grow, since their survival is due to lack of a better economic alternative. The paper adds that although small business owners try to expand, only $2 \%$ actually significantly succeed beyond the typical very marginal existence.

Governments around the world have come to recognize the vital role played by small, medium and micro enterprises (SMMEs) in the achievement of economic growth and development objectives by creating jobs, wealth, and above all, provide satisfying careers for a growing number of entrepreneurs (Walsh and Lipinski, 2009). Botswana Institute of Development and Policy Analysis (BIDPA) report reiterates that SMMEs play an important role in employment creation, especially for the unskilled and semi-skilled, estimated at $75 \%$ of formal sector employment, with over $20 \%$ of GDP, besides their potential in generating 
foreign exchange (BIDPA, 2008). To realize their full potential as an engine of growth, SMMEs need a conducive environment that allows them to prosper and expand, to which government is committed (LEA, 2009).

To foster this critical sector in Botswana, the government formulated a policy framework for the development of SMMEs (Government paper, 1999). This SMME policy is consistent with the theme of sustainable diversification contained in the national development plan 8.The government of Botswana has also supported SMMEs through initiatives such as financial assistance policy (FAP), SMME policy, local enterprise authority (LEA), citizen empowerment development agency (CEDA), reservation of certain businesses for locally owned SMMEs, citizen contractors fund (CCF), and central tenders board preferences (CTBP) (LEA, 2007). Despite the government efforts, the ability for them to survive and prosper entirely depends on how well they implement the marketing concept, by understanding and serving their customers better than their competitors.

Although entrepreneurs/SMMEs may act as catalysts of activity for an entire economy (Bygrave and Minnitti,2000,cited in Naidoo and Boris,2012), many of them fail. One of the reasons for such a high mortality rate is the entrepreneur's lack of managerial skills, which eventually impairs the business (Naidoo and Boris,2012).In developing countries, which is characterized by uncertain market conditions and high failure rates of SMMEs, mere survival may be equated with sustainability and success.SMMEs may be termed successful, if they have endured the first two critical years of existence and the owner has met the majority of his goals and objectives (Kesper,2001,cited in Naidoo and Boris,2012). Others consider a successful business as having been in existence for longer than two years, having a staff component of more than five and less than 30, making a profit and expanding in terms of infrastructure and growth (Nieman et al.,2003,cited in Naidoo and Boris,2012).

\section{1.l.1 Research Objectives}

This research attempts to significantly contribute to the theory and practice of market orientation by testing the hypotheses envisaged, and there by achieving the following objectives:

(i) To assess if the level of market orientation has a significant effect on Business Performance.

(ii) To determine if the level of market orientation has a significant effect on customer satisfaction.

(iii) To determine if the level of market orientation has a significant effect on employee's commitment.

\subsubsection{Significance of the Study}

The service economy has an opportunity to practice market orientation. A market orientation enhances financial and strategic performance. Since integration of principles across organisational boundaries requires a long time. The financial and strategic business performance criteria need to be quantified and cross functional customer feedback 
mechanisms need to be designed. Hence market orientation must be integrated across all service function providers. Market oriented organisations are organisations that are well informed about the market and have the ability to use information advantage to create superior value for their target customers. This study explores the question of adapting a market orientation survey methodology to the specific context of SMMEs service firms in Botswana. This study, thus fulfil an established need for comparative evaluation of market orientation for service firms in Botswana. As a result, implications and appropriate directions more relevant to management are expected to be discerned. This study, thus has implications for SMMEs,aiming at increasing their performance,most especially in Botswana.

This study represents a theoretical gap since the majority of the existing research have concentrated on the manufacturing sector (Aziz and Yassin, 2010), this study extends the existing research to service SMMEs in Botswana. It seeks to test the applicability of MARKOR scale, and operationalize the integrative MO implementation model amongst the service SMMEs in Botswana. Also, this research is hoped to spark numerous studies on market orientation in Botswana, to verify and further the conclusions of this study using different study contexts, scales and industries, and thus significantly contributing to the development of MO concept in Botswana and beyond. This research, thus seeks to expand the body of knowledge about market orientation in practice by extending an established research formula beyond the usual context of developed western economies, and thereby potentially contains lessons for practitioners and researchers in other developing countries. The key intended contribution of the study is further exploration of the market orientation concept within the specific context of small service firms in Botswana. On this basis a modified measurement instrument is suggested that better suits this context and enables comparisons on strategic, but also on more specific, tactical elements. As a result, implications and appropriate directions more relevant to management are expected to be discerned.Thus,it is therefore pertinent to explore what the managers considered to be the principal thrusts of market orientation. This is consistent with Ngai and Ellis,(1998), cited in Ndubisi et al, (2009) request that there is need to test marketing theory in non western environments, as firms in emerging industries and developing economies often lack knowledge about the consumer and can benefit from management and marketing practices that improve information flow from the market place to the producers (Mowat and Collins,2000). Through continual scanning of the market, the organisation can discover underdeveloped market niches and segments, and thereby enhance its competitive position by serving specific markets (Day,1994) and create superior customer value. One of the significant shifts in management considerations within the current market place is a realization that firms often fail to develop a focus on their customers and markets. The change in management thought towards the customer has been spurred by a more competitive business environment, rapid changes in technology which have shortened product life cycles and the increasing power of the consumer. Due to the transformation that has taken place in the market place, management attitudes towards customers and markets are changing. Many organisations are developing formal programmes to enhance quality in production, improve the responsiveness of services offered and promote a renewed commitment to serving the customer. These practices reflect the conscious efforts by management to develop and 
maintain a market orientation within the firm. Thus the aim of this study is,therefore,to empirically test the nomological web of market orientation and business performance and enhance literature on the marketing activities of small businesses in Botswana. This empirical study has policy implications that government may adopt to boost the SMME sector. It seeks to provide a lasting solution to the challenges faced by SMMEs, and particularly in the service industry by making them market oriented, to deliver superior customer value better than its competitors and thus gaining a competitive advantage. This study contributes significantly to a better understanding of how Batswana business managers in the service industry perceive the MO concept and how they can use it in their organisations. It appears imperative that market orientation should be more thoroughly examined,contextually,in order to generate adaptable understanding of the concept and make it more practically interesting to indigenous practitioners. The study also highlight the need for SMMEs to compete effectively by continuously upgrading their business systems by keeping distribution costs low and offering added value to their customers. Thus, the study should be able to make recommendations to business managers on the critical role of marketing orientation in doing business, in competitive markets.

\section{Literature Review}

A dominant position amongst MO pundits is that the firm's degree of MO has a positive effect on business performance (Rojas-Mendez et al. 2006), more especially on sales, market share and profitability (Raaij and Stoelhorst, 2008). Recent studies have provided empirical support for the positive impacts of MO on customer perceived quality, customer satisfaction and loyalty, and employees as well (Jaworski and Kohli, 1996; Kirca et al. 2005; Dauda, 2010). Thus MO is critical to a firm's performance because it encourages and supports new product development to meet current and future market needs. The study of Kara et al. (2005) attests that MO in SMMEs is positively correlated with performance in transitional economies, and particularly China, where their empirical study was conducted. Thus if possible to extrapolate the above findings to any industry and or culture, MO should be expected to have a positive effect on business performance for service SMMEs in Botswana. The basic thrust of research in market orientation has been to examine its linkage with performance. The problem is that the journey from market orientation to business is quite lengthy. As such, with any attempt to bridge the two, a lot of stuff in between may be swept under the rug, resulting in lost insights that managers desperately need. That is, it is nice to know that market orientation and performance are correlated, but it is more important to understand how they are related. Thus far, it has been shown that superior performance may be neither a necessary nor a direct result of market orientation. Put differently, market orientation may not be a sufficient condition for superior performance. Furthermore, market orientation may not even be a necessary condition for superior performance. There are moderating effects influencing the relationship between market orientation and performance. Houston(1986), thus proposed, that, market orientation may not be rewarded uniformly across diverse market conditions.Nwankwo et al.,(2006),concluded that, whilst conceptual explications may seem to be pervasive,implementation has nevertheless continued to reveal fascinating results.Furrer et al.,2004 cited in Nwankwo et al.,(2006),noted that this is largely 
because,despite the different theoretic exhortations offered in the literature,successful implementation of market orientation lies in the orientation of cultural values that embody its interpretation. Agrawal (2003),went further to note that, there is continuing interest in the volume of recent output addressing market orientation across a range of contexts in exploring the links with performance and other relevant outcome variables. However, Diamantopoulos and Hart(1993),have questioned the ambiguity that emerges from developing country context, as regards the impact of market orientation on business performance. Nwankwo et al.,(2006),thus concluded that while there can be little doubt that market orientation delivers superior performance in developed western economies, implementations in many transition economy contexts reveal a range of paradoxes which point to some gaps in both the theory and practice of marketing. While the extant literature helps a great deal in advancing our understanding of the link between market orientation and performance, there are at least three important dimensions in which the literature can be advanced (Sanjaya et. al,2011).First, there is a great deal of ambiguity in the literature about the direction of relationship between market orientation and performance. Secondly, an overwhelming majority of empirical evidence comes from developed economy contexts (Cano et.al.,2004).Many scholars have argued that findings derived from one context may not be applicable to another context, especially,if there are substantial differences in terms of nature and characteristics of firms and business environment (Singh and Gaur,2009).To establish the external validity of findings, we need to amass empirical support from a variety of settings (Sanjaya et.al,2011).Finally, there is conspicuous absence of the discourse on the role market orientation plays in enhancing the performance at the level of business functions (Sanjaya et.al,2011).

However, a number of authors on the concept have questioned the existence of a positive relationship between MO and business performance. Greenley (1995) found existence of no relationship between $\mathrm{MO}$ and business performance. This is corroborated with the findings of Jaworski and Kohli (1993) that MO is not related to a firm's actual market share. While Narver and Slater (1990) report a negative coefficient for MO, Diamantopoulos and Hart (1993, cited in Rojas-Mendez et al., 2006) identified a weak association between MO and business performance. Furthermore, Horng and Chen (1998) in their study of SMMEs in Taiwan, concluded that MO is a critical determinant of business performance, while a study conducted on Greek firms by Salavou et al. (2004), cited in Rojas-Mendez et al, (2006) found that the market orientation strategy does not matter for Greek SMMEs by acting as a catalyst factor in the product innovation process. Theoretically, three recent reviews provide strong evidence that the market orientation-performance relationship is robust. In a meta -analysis of more than 200 effect sizes, Kirca et al.,(2005) found that the effects of market orientation on performance are strongly positive, although somewhat weaker in emerging markets and service industries (Kirca et al.,2005).However, Cano et al.,(2004), found that the effects of market orientation on performance are not moderated by national culture, GDP per capita, or human development and are stronger in service firms than in manufacturing firms. Notably, only three of the 53 studies they examined were located in Low income countries (LICs).They thus theorized that LICs cultural priorities would increase the positive impact of market orientation on performance. This is consistent with Deshpande and Farley's (2004) 
assertion that the effects of market orientation on performance should be highest in LICs markets because the adoption of market orientation is in its early stages in those countries. While earlier studies on MO demonstrated variations on the impacts of MO on a firm's performance, the general trend from above reveal that the latest studies are showing a different picture. Rojas-Mendez et al. (2006) observe that the variations in the findings of studies conducted on MO impacts on business performance in different contexts could be due to variations in the cultural factor, that in turn affect the information dissemination function. Market orientation has been investigated in association with business performance (Avlonitis and Gounaris,1997;Dawes,2000;Matear et al.,2002),cited in Tsiotsou et al.,(2011).A significant stream of research reports a direct positive effect (Jaworski and Kholi, 1993;Deshpande and Farley, 1998; Langerak,2002), cited in Tsiotsou et al.,(2011).Others have examined a mediated relationship (Baker and Sinkula,1999), and finally, research has tested a moderated link (Pelham,1997,cited in Tsiotsou et al.,2011), between market orientation and business performance. However, inconsistencies exist, regarding the market orientation-business performance relation. Explicating the mediators of the market orientation-performance relationship has thus emerged as a topic of interest in marketing literature (Kirca et al.,2005). In an extensive review of related literature, the majority of the studies (68 per cent) investigating a direct relationship between these two constructs reported positive effects, several (30 per cent) found no effects, whereas a small number (2 per cent) indicated negative effects (Langerak,2002., cited in Tsiotsou et al.,2011).This relationship was also tested in the tourism industry and it was found that the degree of market orientation is positively associated with hotels' financial and marketing performance (Sin et al.,2005).

The rationale linking $\mathrm{MO}$ and business performance is that the former facilitates collection and use of market information as well as focusing on coordinating resources to deliver superior customer value ( $\mathrm{Li}$ et al, 2008). Thus a firm with a high degree of MO continuously examines alternative sources of sustainable competitive advantage to determine how it can effectively create superior value and future target customers. Firms that develop better or more appropriate MO tend to pay more attention to understanding and meeting customer needs, understanding the economic environment which they face and responding to changing markets and competitive environments ( $\mathrm{Li}$ et al., 2008) and thus realising superior performance.

Deshpande (1999) observes that whether to be or not to be market oriented, firms should bear in mind that a MO requires commitment of resources and thus the orientation is useful only when the benefits afforded by it exceed the cost of these resources committed. Thus under conditions of limited competition, stable market preferences, technologically turbulent industries, and booming economies, MO may not be particularly strongly related to business performance.

While some empirical studies find a positive relationship between MO and overall business performance (Jaworski and Kohli, 1993) and financial performance (Kara et al., 2005, Kirca et al., 2005, Sin et al., 2005, Kaynak and Kara, 2004), such findings were based on evidence from market economies, and the transitional economy of China (Kara et al., 2005) and developing economy of Chile (Rojas-Mendez et al., 2006). Therefore, it is of scholarly 
prudence that a related empirical study of the impacts of MO on business performance especially for SMMEs in the service industry, be conducted in Botswana to validate the fore mentioned correlations between $\mathrm{MO}$ and business performance. This is very timely as Botswana under goes economic recovery from the global economic recession that has severely hit its SMME sector (BIDPA, 2009 annual report). These SMMEs would then be required to place their emphasis on $\mathrm{MO}$ to obtain significant improvements in their performance. This will also help these firms to adjust their strategies according to the changing market conditions as well as meeting customer needs.

Pelham and Wilson (1996, cited in Li et al., 2008) emphasised, the above juxtaposition that, SMMEs operating under highly uncertain and turbulent environmental conditions should develop MO as an especially effective strategy primarily because of their limited resources. As small firms may have difficulties pursuing other sources of potential business profitability, MO becomes a critical strategic alternative for them (Kara, Spillan, and DeShields, 2005, cited in Li et al., 2008). Jaworski and Kholi (1993),concluded that the link between market orientation and performance is robust through contexts characterised by different levels of market turbulence, competitive intensity and technological turbulence. In this sense, Slater and Narver, (1996), concluded that, given that in the long term all markets will have low growth, high hostility and changes in consumer preferences, being market oriented will never be negative in spite of the negative moderating effect of certain variables acting in the short term. It is logical therefore to hold that SMMEs in the service industry in Botswana that generates market intelligence, disseminates it across all its departments and responds to it, are likely to perform better and have more satisfied customers and employees than those that do not.

\section{Conceptual Development and Hypotheses}

From a focused and sustained meta-analytical review of seminal literature on market orientation, stretching from 1990-2010, the researcher distilled a conceptual framework, in figure 1 below, upon which this study is based. The MARKOR Scale adopted provides a refined direction for the researcher and thus serves as a basis of this empirical study. The framework depicts the three conceptual hypotheses suggested to be tested in this empirical study, focused on measuring the impact of market orientation on business performance of SMMEs in the service industry in Botswana.

H1: the level of market orientation of SMMEs in the service industry in Botswana is related to business performance.

H2: For SMMEs in the service industry in Botswana, the level of market orientation is related to the level of customer consequences.

H3:For SMMEs in the service industry in Botswana, the level of market orientation is related to the level of employees commitment. 


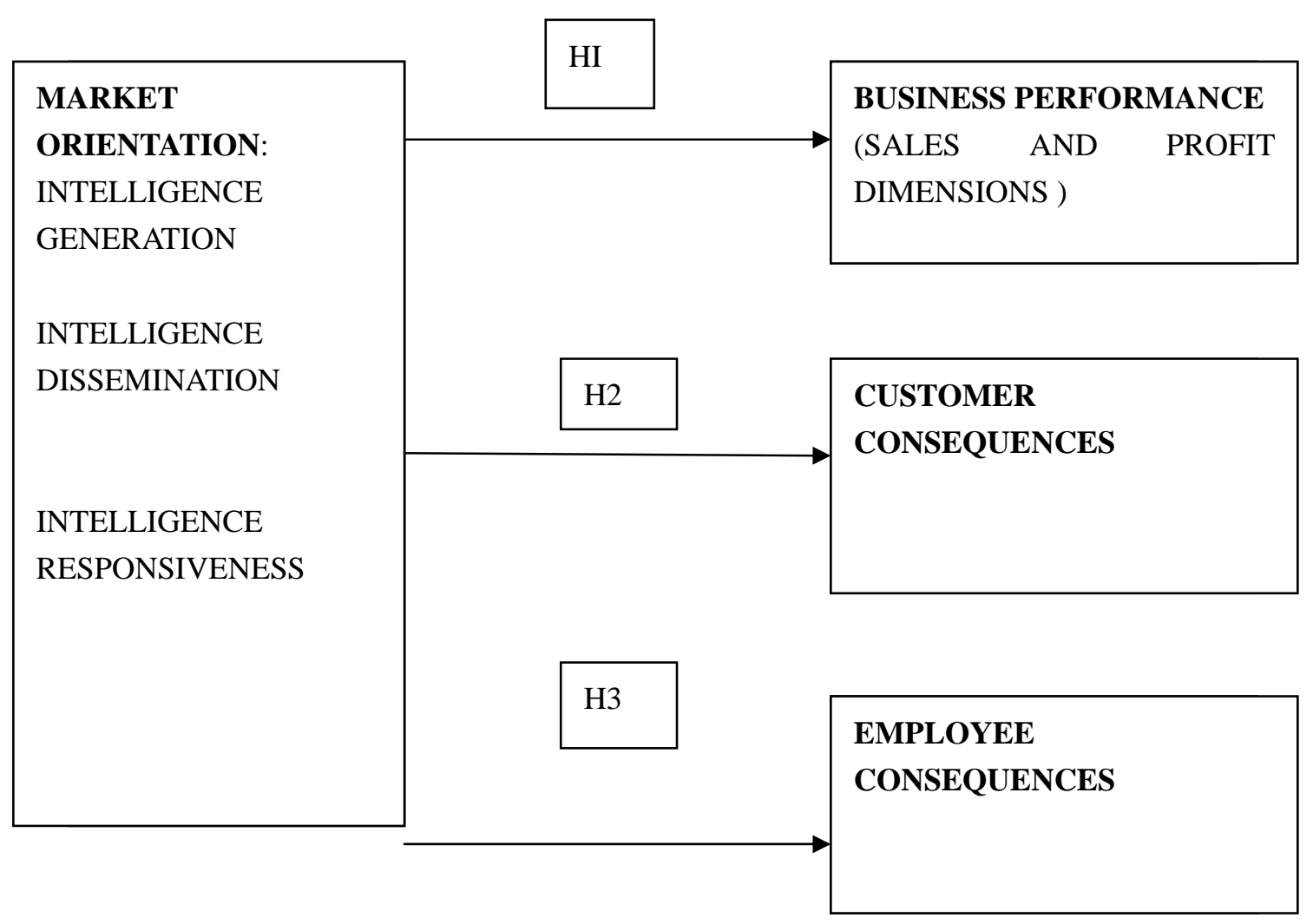

Figure 1. Conceptual Framework Adapted From Kholi And Jaworski,(1993)

\section{Research methodology}

The study employed a snowball sample of managers and business owners in the small service firm domain within Gaborone and its environ. The reason for opting for non-probability rather than probability sampling was that the sampling frame of the key informants was not available and study was exploratory in nature to improve the understanding of organizational market orientation behaviour in Botswana context. These small businesses were operating in the service industry. The final pool of small service firms to whom questionnaires was sent totaled 400.Eventually,only 249 (constituting over 60\% response rate) usable questionnaires were returned by the respondents. Questionnaire was pretested and respondents were asked to identify items they found unclear, ambiguous or confusing. As a result of the pretest, minor adjustments were made to the questionnaire. Data was collected between mid July 2012 to Mid October 2012.The majority of the respondent personnel were managers, accounting for about $50 \%$ of the total. This suggests that most respondents were sufficiently experienced to be able to provide meaningful response to broader policy issues relating to market orientation. After comparing the responses of the early and late respondents, on a number of characteristics, no significant difference was found suggesting that the sample is free from response bias. The sample size and the response rate are consistent with related studies. The questionnaires was developed and scale measures were adopted from Kholi \& Jaworski,(1993) 
constructs.

\section{Results and Discussion}

In this section, results of multivariate analysis of variance (MANOVA) are presented and discussed. In this test, homogeneity of variance for each of the dependent variable was determined in this research setting (Botswana).

Overall market orientation behaviour of small service firms in Botswana has a significant effect on economic (business performance) and non- economic performance (employees'organisational commitment, employees'esprit de corps, customer satisfaction, and repeat customer) of business.

Table 1 below shows that Wilks'Lambda multivariate analysis for the main effect was significant (Wilks'Lambda $=0.810$, F-statistic $=11.230, \mathrm{p}<0.01$ ). This result suggests that both the economic and non-economic performance outcomes of small service firms in Botswana are a function of overall market orientation. This findings thus indicate that overall market orientation has a significant effect on each of the dependent variables of business performance, employees'organisational commitment, employees, esprit de corps, customer satisfaction and repeat customer. In addition, the relationship between economic, non-economic performance and the overall market orientation was very strong as suggested by the Partial Eta ${ }^{2}$ for the dependent variables in Table 1 below.

Therefore, it can be confirmed that hypotheses H1,H2 and H3 are fully supported in this study. That means, that overall market orientation of small service firms in Botswana has a significant effect on both economic and non economic performance of small service firms in Botswana. These findings lend support to Kholi and Jaworski(1990) findings in which they argue that by spreading a sense of pride and camaraderie among employees, market orientation enhances organizational commitment, employee-team spirit and customer orientation.Shoham et al.,(2005) cited in Vieira(2010),concluded that committed employees are more likely to go beyond required norms to contribute to organizational goals and are willing to put more effort into the well being of the organization. This assertion thus resonates with the hypothesis H3:that there is a positive relationship between commitment and market orientation. It could thus be proposed that in Botswana, market orientation perception may strongly improve employees' job satisfaction.

The positive relationship between market orientation and business performance (H1) is consistent with Vieira's(2010),findings, in which he concluded that market orientation helps firms track and respond to changing customer needs. The research finding of significant relationship of market orientation with business performance of small service firms in Botswana, thus establishes tenets of organizational behaviour with respect to a firm's business stakeholders (customers, competitors, and internal functions), which unequivocally makes an impact on organizational performance (Han, Kim,\& Srivastava,1998;Jaworski \& Kholi, 1993; Slater \& Narver,1994,2000;Pelham \& Wilson,1996).

The importance of a customer orientation for firm survival is well acknowledged in the marketing literature. It has been repeatedly argued that firms should sufficiently understand 
their target customers to be able to create superior value for them. Narver and Slater,(1990), cited in Hillenbrand et al.,(2010).Slater and Narver (1994) go further and explain that the heart of a market orientation is a firm's customer focus. To create superior value for buyers continuously requires that a seller understand a buyers' entire value chain, not only as it is today but also as it evolves over time. This statement is consistent with hypothesized relationship (H2) between market orientation and customer consequences in this study.Osuagwu,(2006), concluded that marketing concept is concerned with customer-orientation,innovation and profit as an inducement for creating satisfied customers.

Table 1. MANOVA of Overall Market Orientation(OMO) on Business Performance(BP), employees' organizational commitment(OC), esprit de corps(EDC), customer satisfaction(CS), and repeat customers

\begin{tabular}{|c|c|c|c|c|c|c|}
\hline \multicolumn{6}{|c|}{ Independent Variable: Overall Market Orientation } & \multirow[b]{2}{*}{$\begin{array}{l}\text { Partial } \\
\text { Eta } \\
\text { Squared }\end{array}$} \\
\hline $\begin{array}{c}\text { Dependent } \\
\text { Variables }\end{array}$ & Parameter & B & $\begin{array}{l}\text { Std. } \\
\text { Error }\end{array}$ & t-value & Sig. & \\
\hline \multirow{3}{*}{$\begin{array}{l}\text { Organization } \\
\text { commitment }\end{array}$} & Intercept & 1.144 & 0.032 & 36.153 & 0.000 & 0.843 \\
\hline & Overall market orientation=Disagree) & -0.032 & 0.043 & -0.753 & 0.452 & 0.002 \\
\hline & (Overall market orientation=Agree) & 0 & . & . & . & . \\
\hline \multirow{3}{*}{$\begin{array}{c}\text { Esprit de } \\
\text { corps(Team } \\
\text { spirit) }\end{array}$} & Intercept & 1.865 & b.041 & 45.370 & 0.000 & 0.894 \\
\hline & Overall market orientation=Disagree) & -0.283 & 0.056 & -5.088 & 0.000 & 0.096 \\
\hline & (Overall market orientation=Agree) & 0 & . & . & . & . \\
\hline \multirow{3}{*}{$\begin{array}{c}\text { Business } \\
\text { Performance }\end{array}$} & Intercept & 1.856 & 0.042 & 44.382 & 0.000 & 0.890 \\
\hline & Overall market orientation=Disagree) & -0.371 & 0.057 & -6.558 & 0.000 & 0.150 \\
\hline & (Overall market orientation=Agree) & 0 & . & . & . & . \\
\hline \multirow{3}{*}{$\begin{array}{l}\text { Customer } \\
\text { Satisfaction }\end{array}$} & Intercept & 1.883 & 0.039 & 48.704 & 0.000 & 0.907 \\
\hline & Overall market orientation=Disagree) & -0.196 & 0.052 & -3.755 & 0.000 & 0.055 \\
\hline & (Overall market orientation=Agree) & 0 & . & . & . & . \\
\hline \multirow[t]{3}{*}{ Repeat Customer } & Intercept & 1.243 & 0.041 & 30.509 & 0.000 & 0.793 \\
\hline & Overall market orientation=Disagree) & -0.004 & 0.055 & -0.081 & 0.936 & 0.000 \\
\hline & (Overall market orientation=Agree) & 0 & . & . & . & . \\
\hline $\begin{array}{c}\text { Wilks’Lambda } \\
\left(0.810^{*}\right)\end{array}$ & $\begin{array}{l}\text { F-Statistic } \\
\left(11.230^{*}\right)\end{array}$ & & & & & \\
\hline
\end{tabular}

Significant at the $0.01,0.05$ level, and 0.1 level as $*$, **, and $* * *$ respectively. 
Table 2. Correlation matrix

\begin{tabular}{|c|c|c|c|c|c|c|}
\hline & & $\begin{array}{c}\text { Overall } \\
\text { Market } \\
\text { orientation }\end{array}$ & $\begin{array}{c}\text { Organizational } \\
\text { commitment }\end{array}$ & $\begin{array}{c}\text { Esprit } \\
\text { de } \\
\text { corps }\end{array}$ & $\begin{array}{c}\text { Business } \\
\text { Performance }\end{array}$ & $\begin{array}{c}\text { Customer } \\
\text { satisfaction }\end{array}$ \\
\hline \multirow[t]{3}{*}{ Overall Market orientation } & Correlation & 1.000 & $.167^{*}$ & $.301^{* *}$ & $.336^{* *}$ & $.174^{* *}$ \\
\hline & $\begin{array}{l}\text { Sig. } \\
\text { (2-tailed) }\end{array}$ & & .296 & .000 & .000 & .006 \\
\hline & $\mathrm{N}$ & 249 & 247 & 246 & 246 & 247 \\
\hline \multirow[t]{5}{*}{ Organizational commitment } & Correlation & $.167^{*}$ & 1.000 & $.150^{*}$ & .045 & .079 \\
\hline & Coefficient & & & & & \\
\hline & & .296 & & .019 & .480 & .217 \\
\hline & (2-tailed) & & & & & \\
\hline & $\mathrm{N}$ & 247 & 247 & 245 & 245 & 246 \\
\hline \multirow[t]{5}{*}{ Esprit de corps } & Correlation & $.301^{* *}$ & $.150^{*}$ & 1.000 & $.293^{* *}$ & $.401^{* *}$ \\
\hline & Coefficient & & & & & \\
\hline & & .000 & .019 & & .000 & .000 \\
\hline & (2-tailed) & & & & & \\
\hline & $\mathrm{N}$ & 246 & 245 & 246 & 246 & 246 \\
\hline \multirow[t]{5}{*}{ Business Performance } & Correlation & $.336^{* *}$ & .045 & $.293^{* *}$ & 1.000 & $.447^{* *}$ \\
\hline & Coefficient & & & & & \\
\hline & Sig. & .000 & .480 & .000 & & .000 \\
\hline & (2-tailed) & & & & & \\
\hline & $\mathrm{N}$ & 246 & 245 & 246 & 246 & 246 \\
\hline \multirow[t]{5}{*}{ Customer satisfaction } & Correlation & $.174^{* *}$ & $.179^{* *}$ & $.401^{* *}$ & $.447^{* *}$ & 1.000 \\
\hline & Coefficient & & & & & \\
\hline & Sig. & .006 & .217 & .000 & .000 & \\
\hline & (2-tailed) & & & & & \\
\hline & $\mathrm{N}$ & 247 & 246 & 246 & 246 & 247 \\
\hline
\end{tabular}

**. Correlation is significant at the 0.01 level (2-tailed).

*. Correlation is significant at the 0.05 level (2-tailed).

\section{Conclusion and Recommendation}

The study findings generally resonate with the results of Jaworski and Kholi (1993),as well as Narver and Slater,(1990).It also offers one more support for the robustness of Jaworski and Kholi's (1993) model. The importance of the impact of market orientation on business performance among small service firms suggests the need for a better understanding of the organizational forces that determine the degree and shape the direction of a market oriented 
culture within the firm. The significant effect of market orientation on Botswana's small service firms is not only reflected in superior financial performance (sale and profit dimensions), but has also been linked to other factors that are beneficial to the customers, the firm and its employees, and the society in general. Market orientation therefore provides small service firms with ways to connect with the market,customers,and employees in order to improve organizational growth and profitability which are required for its competitiveness and survival. Findings, thus paradoxically reveal that market orientation is the most appropriate strategic option that could influence customer satisfaction, team spirit, business performance and repeat purchase. The methods and instruments used in this study could thus be utilized by managers and investors to analyse, monitor, and measure their firms market orientation behaviours and performance.

This study sought to examine the relationship between market orientation and business performance. The study results thus provide strong support for the basic proposition that market orientation influences the overall performance of small service firms in Botswana. Moreover, it is the market information and marketing strategy formulation dimensions that appear to be critical to overall performance. Therefore, while the implementation of marketing strategy could be important, it is the collection and dissemination of market information and formulation of appropriate marketing strategies that are critical to the overall success of Botswana's small service firms.

The findings of this study support the call for more targeted training interventions where operations are core to the survival of many small businesses. Skills transference by means of training and outcome-based education, using interactive workshops, which are based on action learning and role playing, are recommended. As part of government's initiative to empower and enhance the skills of small business owners, policies should encourage the development of specific functional skills of which market orientation behaviour is central to sustainability.

\section{Limitation and Further research Direction of the study}

From the methodological point of view, the non-probabilistic sample data collection procedure may impose some limitations to the external validity of the findings. Moreover, since it is a cross-sectional data, the results might not be interpreted as proof of a causal relationship but rather lending support for the previous causal scheme. Also, this study's results are based on small service firms that were included based on snowball sampling. Therefore, the study's findings have limited generalizability and may not be extended to other environments. When investigating the relationship between market orientation and the firm performance, future studies should also consider different performance measures, such as market share, return on investment, and data should be collected from multiple informants. Some additional antecedents of market orientation including professionalism, entrepreneurship, company size and resources, political unrests and nepotism, culture, lack of efficient manpower, as well as legal environment may be included in the conceptual framework to examine their relationships with overall market orientation. In spite of the claims of other researchers that no significant differences exist in the responses in the 
utilization of a single respondent or multiple respondents, it would be interesting if the future studies employ multiple respondents within the organizations.

\section{References}

Aziz, N. A., \& Yassin, N.M. (2010). How Will Market Orientation and External Environment Influence the Performance among SMEs in the Agro-Food Sector in Malaysia. Journal of international Business Research, 3(3), 154-164.

BIDPA. (2008). Botswana Institute of Development and Policy Analysis Profile.

Boris Urban, and Reggie Naidoo,(2012), Business sustainability: empirical evidence on operational skills in SMEs in South Africa. Journal of Small Business and Enterprise Development, 19(1), 146-163.

Burgess, S. M., \& Nyajeka, P. (2007). Market orientation and performance in low-income countries: The case of Zimbabwean retailers. Advances in International Management Journal, 20, 215-257.

Cano,C.R., Carrillat,F.A., \& Jaramillo, F. (2004). A meta-analysis of the relationship between market orientation and business performance: evidence from five continents. International Journal of Research in Marketing, 21, 179-200.

Dauda, A. Y. (2010) Employee's Market orientation and business performance in Nigeria: Analysis of small business enterprises in Lagos state. International Journal of Marketing Studies, 2(2), 134-143. Available at: www.ccsenet.org/ijms. (Accessed on 3rd Nov 2010).

Day, G. S. (1994)._The capabilities of market driven organizations. Journal of Marketing, 58, 37-52.

Deshpande, R., Farley, J., \& Webster, E. F. (1993). corporate culture, customer orientation and innovativeness in Japanese firms: A quadrad analysis. Journal of Marketing, 57(1), 23-37. http://dx.doi.org/10.2307/1252055.

Farrell, M. (2002). A critique of the development of alternative measures of market orientation. Marketing bulleting, 13, 1-13.

Fisk,R.P., Brown,S.W., \& Bitner, M.J. (1993). Tracking the evolution of the services marketing literature. Journal of Marketing Research, 69(1), 61-103.

Greenly, G.E. (1995). Market orientation and company performance: empirical evidence from UK companies. British Journal of Management, 6, 1-13. http://dx.doi.org/10.1111/j.1467-8551.1995.tb00082.x

Han J. K., Kim. N., \& Srivastava. R. K. (1998). Market orientation and organizational performance: is innovation a missing link. Journal of Marketing, 62, 30-45. http://dx.doi.org/10.2307/1252285.

Hinton, P., Mokobi, U., \& Sprokel, C. (2006) Botswana small and medium enterprise under banked market research. Enterprise banking group. Gaborone. 
Horng, S., \& Chen C. (1998). Market Orientation of Small and medium-sized Firms in Taiwan. Journal of Small Business Management, 36(3), 79-85.

Houston,F.S. (1986), The marketing concept: what it is and what it is not. Journal of Marketing, 50, 1-15.

Hunt S. D., \& Morgan R. M. (1995). The comparative advantage theory of competition. Journal of Marketing, 59, 53-70.

Jaworski, B. J., \& Kohli, K. A. (1993) Market orientation: antecedents and Consequences. Journal of marketing, 57(3), 53-70. http://dx.doi.org/10.2307/1251854

Kara, A., Spillan, J. E., \& DeShields, O. (2005).The effects of a market orientation on business performance: a study of small-sized service retailers using MARKOR scale. Journal of Small business management, 43(2), 105-118. http://dx.doi.org/10.1111/j.1540-627x.2005.00128.x

Kaynak E, \& Kara A (2004). Market orientation and organizational performance: A comparison of industrial versus consumer companies in Mainland China using market orientation scale (MARKOR). Ind. Mark. Management, 33(5), 743-753. http://dx.doi.org/10.1016/j.indmarman.2004.01.003.

Keskin, H. (2006). Market orientation,learning orientation, and innovation capabilities in SMEs (An extended model)._European Journal of Innovation Management, 9(4), 396-417.

Kirca, A. H., Jayachandran, S., \& Bearden, W. O. (2005). Market orientation: a meta-analytic review and assessment of its antecedents and impact on performance. Journal of Marketing. . 69(2), 24-41. http://dx.doi.org/10.1509/jmkg.69.2.24.60761

Kohli, K.A., \& Jaworski, J.B. (1990) market orientation: the construct, research propositions and managerial implications. Journal of marketing, 54(2), 1-18. http://dx.doi.org/10.2307/1251866.

Kohli, K.A., Jarworski, J.B., \& Kumar, A. (1993). MARKOR: A measure of market orientation. Journal of Marketing Research, 30(4), 467-477.

Kohli, A. K., \& Jaworski, B. J. (1990). Market Orientation: The construct, Research Propositions, and Managerial Implications. Journal of Marketing, 54(2), 1-18.

Krepapa, A., Berthon, P., Webb, D., \& Pitt,L. (2003). Mind the gap. An analysis of service provider versus customer perceptions of market orientation and the impact on satisfaction. European Journal of Marketing, 37(1/2), 197-218.

Kuada,J., \& Buatsi, S. N. (2005). Market orientation and management practices in Ghanaian firms: Revisiting the Jaworski and Kholi framework. Journal of International Marketing, 13(1), 58-88.

Lafferty, B. A., \& Hult, G. T. M. (2001). A synthesis of contemporary market orientation perspectives. European Journal of marketing, 35 (1/2), 92. 
Langerak, F. (2003). The effect of market orientation on positional advantage and organizational performance._Journal of strategic marketing, 11(2), 93.

LEA. (2009). Needs Assessment For SMMEs Sector and Business Development Service Providers. Final Report. Gaborone, LEA.

LEA. (2007). A study commissioned on small, medium and large enterprises database, sector mapping and validation in Botswana: findings and strategies for local enterprise authority (LEA) in the Republic of Botswana. Gaborone, LEA.

Li, Y., Zhao, Y., Tan, J., \& Liu, Y. (2008). Moderating effects of entrepreneurial orientation on market orientation - performance linkage: Evidence from Chinese small firms. Journal of Small Business Management, 46(1), 113-133. http://dx.doi.org/10.1111/j.1540-627X.2007.00235.x

Marandu, E.E., \& Themba,G. (2012), The Effects of Market Orientation on Employees: A Study of Retail Organisations in Botswana. International Business Research, 6(1), 130-136.

Mowat, A., \& Collins, R. (2000), Consumer behaviour and fruit quality: supply chain management in an emerging industry, Supply Chain Management: An International Journal, 5(1), 45-54.

Narver, J. C., \& Slater, S. F. (1990). The Effect of a market orientation on business profitability. Journal of marketing, 54(4) 20-35. http://dx.doi.org/10.2307/1251757.

Narver, J.C., \& Slater, S. F. (1994a). Does competitive environment moderate the market orientation performance relationship?_Journal of Marketing, 58(1), 46.

Ndubisi,N.O., \&Matanda,M.J. (2009.) Market orientation, supplier perceived value and business performance of SMEs in a Sub-Saharan African nation. Journal of Enterprise Information Management, 22(4), 384-407.

Nwankwo, S.,Zhang,Y.,Omar.,M, \& Bathgate.,I. (2006). Transition to a market orientation in China: preliminary evidence. Marketing Intelligence \& Planning, 24(4), 332-346.

Osuagwu L. (2006). Market orientation in Nigerian companies,Marketing Intelligence. Planning, 24(6), 608-631.

Pelham, M. A. (2005). Market orientation and other potential influences on performance in small and medium-sized manufacturing firms. Journal of small business management, 43(2), $1-4$

Raaij, V. M. E., \& Stoelhorst, W. J. (2008) The implementation of market orientation - a review and integration of contributions to date. European Journal of Marketing, 42(11/12), 1265-1293. http://dx.doi.org/10.1108/03090560810903673.

Republic of Botswana. (1999) .Government Paper No. 1 of 1999: Policy on small medium and micro enterprises in Botswana. Government printer, Gaborone.

Republic of Botswana. (1998). Government Paper No. 1 of 1998: Industrial development 
policy for Botswana. Government printer, Gaborone.

Rojas-Mendez, I. J., Kara, A., \& Spillan, E. J. (2006). Market Orientation in the Chilean Small Business Context: An Empirical Study. Journal of Global Marketing, 19(3/4), 93-132 http://dx.doi.org/10.1300/J042v19n03-05.

Ruekert, R. W. (1992). Developing a market orientation: An organizational strategy perspective. International Journal of research in marketing, 9(3), 225-245.

Sanjaya, S.G.,Vasudevan,H., \& Ajai,S.G. (2011). Market orientation and manufacturing performance of Indian SMEs: Moderating role of firm resources and environmental factors, European Journal of Marketing,.45(7), 1172-1193.

Sin,L., Tse, A., Heung, V., \& Yim, F. (2005). An analysis of the relationship between market orientation and business performance in the hotel industry. Hospitality Management, 24(4), 555-577.

Tsiotsou,R.H., \& Vlachopoulou, M. (2011). Understanding the effects of market orientation and e-marketing on service performance. Marketing Intelligence and Planning, 29(2), 141-155.

Vieira V.A (2010). Antecedents and consequences of Market Orientation: a Brazilian meta-analysis and an international mega-analysis. Brazilian Administration Review,Curitiba, $7(1), 44-58$

Walsh, F. M., \& Lipinski, J. (2009) The role of the marketing function in small and medium sized enterprises. Journal of small business and enterprise development, 16(4), 569-585. http://dx.doi.org/10.1108/14626000911000929.

Zebal,M.A., \& Goodwin,D.R.(2011) Market Orientation in a Developing Nation-Antecedents, Consequences and the Moderating Effect of environmental Factors. Marketing Bulletin, 22, $1-23$. 